\title{
ON VAGAL AND EXTRAVAGAL FACTORS IN CARDIAC SLOWING BY DIGITALIS IN PATIENTS WITH AURICULAR FIBRILLATION
}

\author{
BY HARRY GOLD, NATHANIEL T. KWIT, HAROLD OTTO, AND \\ THEODORE FOX
}

\begin{abstract}
(From the Department of Pharmacology, Cornell University Medical College, the Hospital for Joint Diseases, and the Beth Israel Hospital, New York City)
\end{abstract}

(Received for publication March 25, 1939)

The improvement of the circulation produced by digitalis in patients with auricular fibrillation is almost invariably associated with slowing of ventricular rate. Whether the improvement is the cause of the slowing, or the result of it, or in part a cause and in part a result of the slowing are matters concerning which opinion is divided. The extent to which the slowing causes the improvement could be established if the slowing could be prevented. It appeared that this problem might be attacked by the use of repeated doses of atropine to prevent the cardiac slowing over a period of several days after a massive dose of digitalis. The influence of digitalis on the heart failure as measured by changes in body weight, fluid loss, and subjective symptoms in these cases might then be compared with its well-known effect in patients in whom the rate is permitted to become slow.

The effect of atropine on the heart rate of digitalized patients with auricular fibrillation has been the subject of several reports in the literature, and while views were not entirely in agreement, there seemed to be sufficient accord to indicate that with adequate doses of atropine little difficulty would be encountered in maintaining a rapid heart rate after large doses of digitalis in a considerable proportion of the patients.

A study was planned to pursue this matter, but the original objective ceased to appear promising after several results were obtained, for they showed what was confirmed by subsequent observations, that the experiment could not be carried out, that atropine, even in doses causing severe systemic symptoms, could not prevent the pronounced slowing of the ventricle after very large doses of digitalis. The inference we drew from the literature, therefore, proved to be incorrect, and a reexamination of the literature disclosed the fact that the discordant observations and conflicting conclusions concerning the rôle of the vagus could not be harmonized by existing data alone.

\section{IITERATURE}

While there are numerous reports on the effect of atropine on the ventricular rate which has been slowed by digitalis, the studies of Cushny, Marris, and Silberberg (1), and Lewis, Drury, Wedd, and Iliescu (2) present the more detailed analyses of the subject. Cushny et al. (1) concluded that " in auricular fibrillation, digitalis and its allies slow the heart from some direct action on the heart and not from stimulation of the inhibitory mechanism, for atropine does not restore the original rate of the released heart." About 10 years later, Lewis et al. (2), on the other hand, concluded that the ventricular slowing caused by digitalis is in part due to a direct action on the ventricle and in part to vagal stimulation, and that the different proportions of these actions in different cases were chiefly matters of individual variation, both actions being exerted " in different proportions from case to case." In the 10 digitalized patients of Cushny et al. the average ventricular rate after atropine was only 79 a minute, whereas in the 8 patients of Lewis et al. it was 137 a minute. Lewis et al. attributed this difference to the inadequate doses of atropine used by Cushny et al., for Lewis found that after digitalis it took more atropine completely to block the vagus than before digitalis, and that a dose of $1 / 50$ grain subcutaneously (doses used by Cushny et al.) was not sufficient. In his review of these earlier observations, Cushny (3) stated, "it seems possible that the relative importance of the two factors may vary ... with different doses of the drug." He suggested that the dissimilar results were not due to differences in the doses of atropine but of digitalis. He stated that the evidence of more intense digitalization in his own cases was a greater fall in the pulse rate. The records, however, do not support this statement, for the average pulse rates in the 2 series of cases were practically identical : Cushny et al., before digitalis 103 per minute, after digitalis 65; Lewis et al., before digitalis 106, after digitalis 65 . The different results obtained in the two series of cases remained therefore unexplained. Cushny suggested other factors which might determine whether the rate was slowed chiefly by one or the other mechanism: individual peculiarities, the condition of the heart, and the length of time that the heart had been under the influence of digitalis, 
"the longer the drug acts the less the role played by the vagus, and the greater that of direct impairment of the A-V fibers."

In his monograph, Robinson (4) called attention to the prevailing uncertainty as to whether the action of digitalis on conduction "should be regarded mainly as an effect of vagus stimulation or as an effect produced by the direct action of the drug on the heart." More recently (5) Elsie Porter reported some new experiments on subjects with auricular fibrillation from which she took the position that the cardiac slowing is entirely vagal, and that "if and when a larger dose of atropin can be safely given intravenously, the whole digitalis effect will be found to fall upon the vagus."

In view of the unsettled state of the matter, our experiments were extended to explore further the effect of maximum doses of atropine on the heart rate in auricular fibrillation after various doses of digitalis in one and the same individual, in different individuals, and under different conditions. The results of these are presented in the present report.

\section{METHOD}

Patients. The experiments were performed on 9 subjects with organic heart disease. In 8 of these there was an advanced degree of heart failure with congestion, and in 1 there were no signs or symptoms of heart failure. All had a persistent auricular fibrillation. The characteristics of the group are summarized in Table I. The patients were admitted to the hospital and kept in bed. In addition to the routine laboratory tests, includ-

TABLE I

Description of patients with auricular fibrillation used in this study

\begin{tabular}{|c|c|c|c|c|}
\hline Case & Age & Sex & Weight & Diagnosis \\
\hline 1 & $\begin{array}{c}\text { years } \\
65\end{array}$ & Male & $\begin{array}{c}\text { pounds } \\
182\end{array}$ & Hypertension, enlarged heart \\
\hline 2 & 42 & Male & 183 & Unknown etiology, enlarged heart \\
\hline 3 & 44 & Female & 93 & $\begin{array}{l}\text { Unknown etiology, mitral stenosis and } \\
\text { insufficiency, enlarged heart }\end{array}$ \\
\hline 4 & 55 & Male & 134 & $\begin{array}{l}\text { Hypertension and arteriosclerosis, en- } \\
\text { larged heart, syphilis }\end{array}$ \\
\hline 5 & 44 & Male & 155 & $\begin{array}{l}\text { Unknown etiology, mitral stenosis and } \\
\text { insufficiency, enlarged heart }\end{array}$ \\
\hline 6 & 35 & Female & 130 & $\begin{array}{l}\text { Rheumatic fever, mitral stenosis and } \\
\text { insufficiency, enlarged heart }\end{array}$ \\
\hline 7 & 56 & Male & 130 & $\begin{array}{l}\text { Rheumatic fever, mitral stenosis and } \\
\text { insufficiency, aortic insufficiency, en- } \\
\text { larged heart }\end{array}$ \\
\hline 8 & 29 & Male & 131 & $\begin{array}{l}\text { Rheumatic fever, mitral stenosis and } \\
\text { insufficiency, aortic stenosis and } \\
\text { insufficiency, enlarged heart }\end{array}$ \\
\hline 9* & 40 & Female & 135 & $\begin{array}{l}\text { Rheumatic fever, mitral stenosis and } \\
\text { insufficiency, enlarged heart; de- } \\
\text { veloped auricular fibrillation after } \\
\text { hemorrhoidectomy while in the } \\
\text { hospital; had had thyroidectomy } 18 \\
\text { years ago for exophthalmic goiter, } \\
\text { but now has a normal metabolic rate }\end{array}$ \\
\hline
\end{tabular}

* All had advanced congestive heart failure, except this patient who never had signs or symptoms of failure. ing electrocardiograms and the daily clinical examinations, their fluid intake and output, and ventricular and pulse rates were charted. They were weighed on admission and again usually every third day. The fluid intake was fixed at approximately a liter a day. The control period was continued until a fairly fixed level was reached for ventricular rate, body weight, and water balance. The control period lasted up to 16 days, but was terminated as early as 3 days after admission in 3 cases in which the heart failure appeared to be growing rapidly worse. During the control period digitalis and diuretics were withheld.

Digitalis. The drug was administered in the form of compressed tablets of the powdered leaf standardized by the cat method. All but Case 9 received digitalis with a potency of $97 \mathrm{mgm}$. per cat unit. A dose of 0.14 to 0.2 cat unit per pound of body weight (24 to 54 grains) was given at one time in 6 cases; in 4 of these, additional doses were given subsequently. Two cases received smaller doses at the start, but a total of 0.14 and 0.46 cat unit per pound in 2 and 13 days respectively. These doses were sufficient to induce toxic symptoms in 4 of the 9 patients (Table II). In calculating the dose, no allowance was made for the amount of edema fluid. Case 9 received a specimen of digitalis with a cat unit potency of $85 \mathrm{mgm}$.

Atropine. Enough atropine was given to abolish completely the vagal control of the ventricular rate. The dose which appeared sufficient to accomplish this was 1/30 grain $(2.16 \mathrm{mgm}$.) of atropine sulfate by intravenous injection, as shown by the fact that the release of the heart rate produced by this dose was in no instance increased by more of the drug (tested in 6 experiments). In all, 36 intravenous doses of atropine sulfate were administered in a concentration of 0.2 per cent in physiological salt solution. These were given in single doses of $1 / 00$ grain or $1.08 \mathrm{mgm}$. (3 doses), $1 / 30$ grain or 2.16 mgm. (25 doses), 1/25 grain or $2.6 \mathrm{mgm}$. (5 doses), 1/20 grain or $3.2 \mathrm{mgm}$. (2 doses), and $1 / 15$ grain or $4.3 \mathrm{mgm}$. (1 dose). In one case a total of $1 / 11$ grain $(6 \mathrm{mgm}$.) was given in 2 hours and in another a total of $1 / 6$ grain (13 mgm.) was given in 24 hours. As already indicated, the maximum effect on the rate resulted from $1 / 30$ grain, and larger doses served merely to intensify the toxic symptoms. These doses are substantially similar to those found necessary to obtain maximum ventricular release in experiments by Lewis, Drury, Wedd, and Iliescu (2).

The ventricular rate was counted with the stethoscope at the apex, a count of a half minute being taken at intervals of 1 to 2 minutes at first, and then at longer intervals. In one case the rate was counted on electrocardiograms taken at similar intervals. The maximum acceleration of the rate was in evidence within a minute or two. Partial recovery, however, occurred fairly rapidly; as much as a half of the acceleration might disappear within about 15 minutes. The complete return of the rate to the pre-atropine level after the dose of $1 / 30$ grain was more gradual, sometimes not quite complete even after about 5 or 6 hours. Some delay in the return may be due to restlessness induced by the atropine. It 
TABLE II

Summarizing effect of atropine on ventricular rate after different doses* of digitalis

\begin{tabular}{|c|c|c|c|c|c|c|c|}
\hline \multirow{2}{*}{ †Case } & \multirow{2}{*}{$\begin{array}{l}\text { Ven- } \\
\text { tric- } \\
\text { ular } \\
\text { rate } \\
\text { be- } \\
\text { fore } \\
\text { digi- } \\
\text { talis }\end{array}$} & \multirow{2}{*}{$\begin{array}{l}\text { Total } \\
\text { digi- } \\
\text { talis } \\
\text { dose }\end{array}$} & \multirow{2}{*}{$\begin{array}{l}\text { Toxic } \\
\text { effect of } \\
\text { digitalis }\end{array}$} & \multirow{2}{*}{$\begin{array}{c}\text { Interval } \\
\text { between } \\
\text { beginning } \\
\text { of digi- } \\
\text { talization } \\
\text { and } \\
\text { atropine }\end{array}$} & \multicolumn{2}{|c|}{$\begin{array}{l}\text { Ventricular } \\
\text { rate }\end{array}$} & \multirow{2}{*}{$\begin{array}{l}\text { Per cent } \\
\text { of the } \\
\text { digitalis } \\
\text { slowing } \\
\text { abolished } \\
\text { by } \\
\text { atropine }\end{array}$} \\
\hline & & & & & $\begin{array}{l}\text { Be- } \\
\text { fore } \\
\text { atro- } \\
\text { pine }\end{array}$ & $\begin{array}{l}\text { After } \\
\text { atro- } \\
\text { pine }\end{array}$ & \\
\hline & $\underset{\substack{\text { per } \\
\text { min- } \\
\text { ute }}}{ }$ & grains & & & 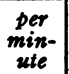 & $\begin{array}{c}\text { per } \\
\text { min- } \\
\text { ute }\end{array}$ & per cent \\
\hline \multicolumn{8}{|c|}{ A.‡ PREDOMINANTLY VAGAL ACTION (SMALLER DOSES) } \\
\hline 1 & 148 & 54 & None & 2 hours & 133 & 152 & $100(127) \&$ \\
\hline 2 & 145 & $\begin{array}{l}42 \\
42\end{array}$ & $\begin{array}{l}\text { None } \\
\text { None }\end{array}$ & $\begin{array}{l}2 \text { hours } \\
4 \text { days }\end{array}$ & $\begin{array}{r}114 \\
71\end{array}$ & $\begin{array}{l}164 \\
161\end{array}$ & $\begin{array}{l}100(161) \\
100(122)\end{array}$ \\
\hline 3 & 128 & $\begin{array}{l}24 \\
24\end{array}$ & $\begin{array}{l}\text { None } \\
\text { None }\end{array}$ & $\begin{array}{l}10 \text { hours } \\
22 \text { hours }\end{array}$ & $\begin{array}{l}81 \\
61\end{array}$ & $\begin{array}{l}141 \\
140\end{array}$ & $\begin{array}{l}100(128) \\
100(117)\end{array}$ \\
\hline 4 & 118 & $\begin{array}{l}30 \\
42(a)\end{array}$ & $\begin{array}{l}\text { None } \\
\text { None }\end{array}$ & $\begin{array}{l}8 \text { hours } \\
19 \text { hours }\end{array}$ & $\begin{array}{l}93 \\
76\end{array}$ & $\begin{array}{l}128 \\
105\end{array}$ & $\begin{array}{r}100(140) \\
70(70)\end{array}$ \\
\hline 8 & 86 & $27(b)$ & None & 4 days & 58 & 85 & 97 (97) \\
\hline 9 & 134 & $60(c)$ & None & 8 days & 90 & 133 & $98(98)$ \\
\hline
\end{tabular}

B. PREDOMINANTLY EXTRAVAGAL ACTION (LARGER DOSES)

\begin{tabular}{l|c|l|l|l|r|r|l}
\hline 1 & 148 & 54 & Vomited $(d)$ & 23 hours & 75 & 92 & 23 \\
2 & 145 & $78(e)$ & None & 14 days & 56 & 70 & 16 \\
3 & 128 & $117(f)$ & Vomited & 10 days & 75 & 100 & 47 \\
& & $117(f)$ & & 6 days, & 75 & 90 & 28 \\
& & $117(f)$ & & 11 dayrs & 45 & 88 & 52 \\
5 & 118 & $75(g)$ & Coupling & 12 days & 60 & 90 & 52 \\
5 & 134 & 35 & Vomited $(h)$ & 8 hours & 64 & 89 & 36 \\
6 & 115 & $56(i)$ & None & 8 days & 64 & 88 & 34 \\
7 & 132 & 27 & None & 5 hours & 84 & 105 & 68 \\
9 & 134 & $87(c)$ & None & None days & 86 & 99 & 45 \\
& & 18 days & 52 & 68 & 20 \\
\hline
\end{tabular}

* Unless otherwise stated, the entire dose was given at one time.

t Cases 1, 2, 3, 4 and 9 were tested after both smaller and larger doses.

$\ddagger$ Borderline cases could not be satisfactorily classified.

8 Figures in this column indicate not only release of digitalis slowing but acceleration above the rate in the control, prior to digitalis.

(a) 12 grains more on Day 1. (In all cases, the days are reckoned from the first day on which digitalis is given.)

(b) 15 grains on Day 1 and 12 grains on Day 2.

(c) See Figure 6

(d) 9 hours after digitalis.

(e) 12 grains on Days 6, 7, and 8

(f) 12 to 18 grains daily on Days 3 to 9.

(g) 12 grains on Days 5 and 6, 6 grains on Day 7, and 3 grains on Day 10.

(h) 11 hours after digitalis.

(i) 3 grains daily on Days 2 to 8 .

(j) 21 grains on Day 1, 12 grains on Days 2 to 5 , and 3 grains on Days 6 to 13.

may be inferred that the fairly rapid recovery of the slow heart rate after a dose of atropine is due, at least in part, to mechanisms other than elimination of the drugs, since additional doses, even larger ones, usually failed to raise the ventricle to the maximum rate prevailing after the first dose, when the second was given during what appeared to be considerable recovery from the first. Figure 1 illustrates the types of atropine curves. Lewis et al. (2) also observed the rapid recovery and attributed it in part to reflex stimulation of the vagus center (" increased afferent impulses playing on the vagal center") as the result of the sudden cardiac acceleration. The possibility of sympathetic depression (synapse of the ganglion) or some direct muscular depression by atropine cannot be excluded. In connection with another study (6) we observed brief sinus slowing and prolonged $\mathrm{P}-\mathrm{R}$ intervals after a large dose of atropine in digitalized animals. Similar effects under special conditions were reported by Lewis et al. (2). Whether such effects play any part in the return to the slow rate after atropine cannot be stated.

\section{RESULTS}

Atropine cannot prevent cardiac slowing. Figure $2^{1}$ shows the course of events in the endeavor to secure full digitalis effect without ventricular slowing. In Case 2, the first dose of atropine ( $1 / 30$ grain) was given 1 hour and 46 minutes after the oral dose of $\mathbf{4 2}$ grains of digitalis. A second similar dose of atropine was given 1 hour and 27 minutes after the first, and the third dose of $1 / 60$ grain was given 1 hour and 34 minutes after the second, in all $1 / 12$ grain in a period of 3 hours and 1 minute. These doses caused atropine poisoning with stupor, restlessness, muttering, dryness, and dilated pupils, symptoms which became more intense as the doses were repeated. As may be seen, however, the release of the ventricle was only temporary, was diminished with the repetition of the dose, and the release was almost negligible after the last dose, indicating that the vagus was in all probability completely blocked. Nevertheless, the ventricular rate continued to fall as the absorption of digitalis progressed, and about 12 hours after the administration of the drug the rate had fallen from 145 to 85 while the patient was under the influence of sufficient atropine to cause severe toxic effects. In Case 1, the phenomena were essentially the same with even larger doses of atropine.

These results show, therefore, that even when

1 In order to simplify inspection of these curves some of the points which come very close together have been omitted without significantly influencing the course of the curves. This sometimes had the effect of smoothing out minor irregularities in the curves. 


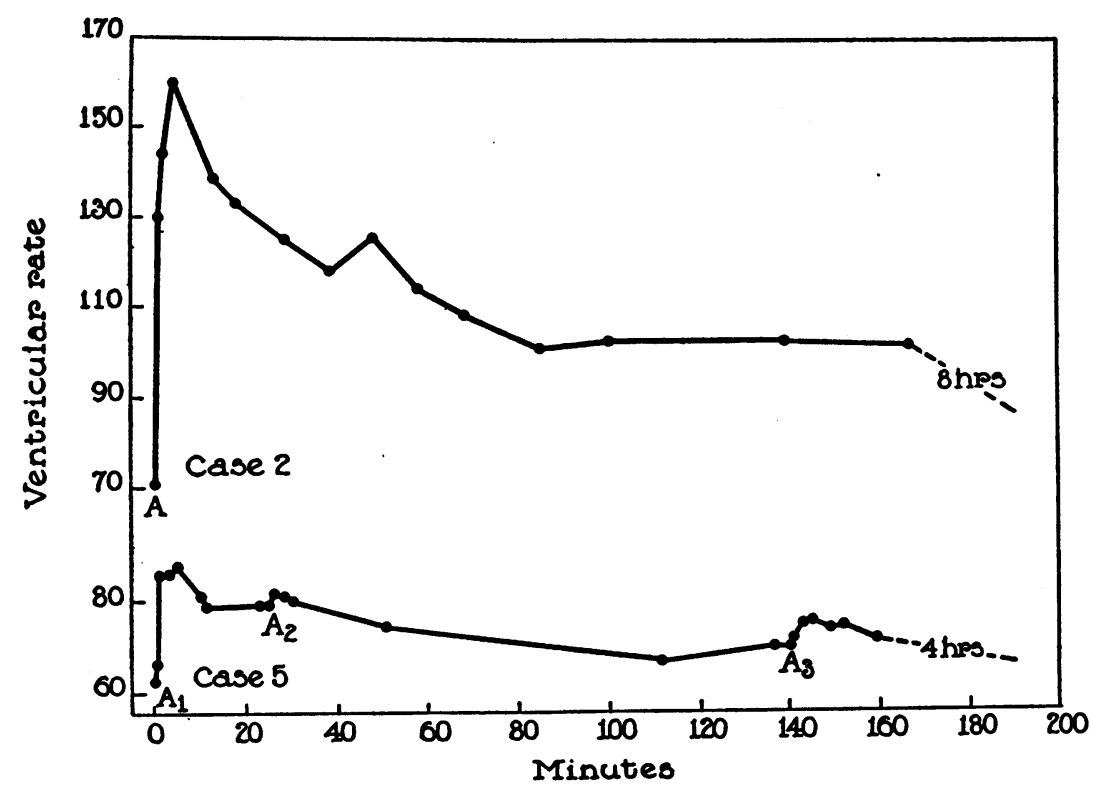

Fig. 1. Types of Atropine Efrects

Case 2. (A) represents $1 / 50$ grain atropine sulfate given intravenously after marked slowing by a full dose of digitalis.

Case 5. Each (A) represents $1 / 60$ grain atropine sulfate given intravenously after marked slowing by a full dose of digitalis.

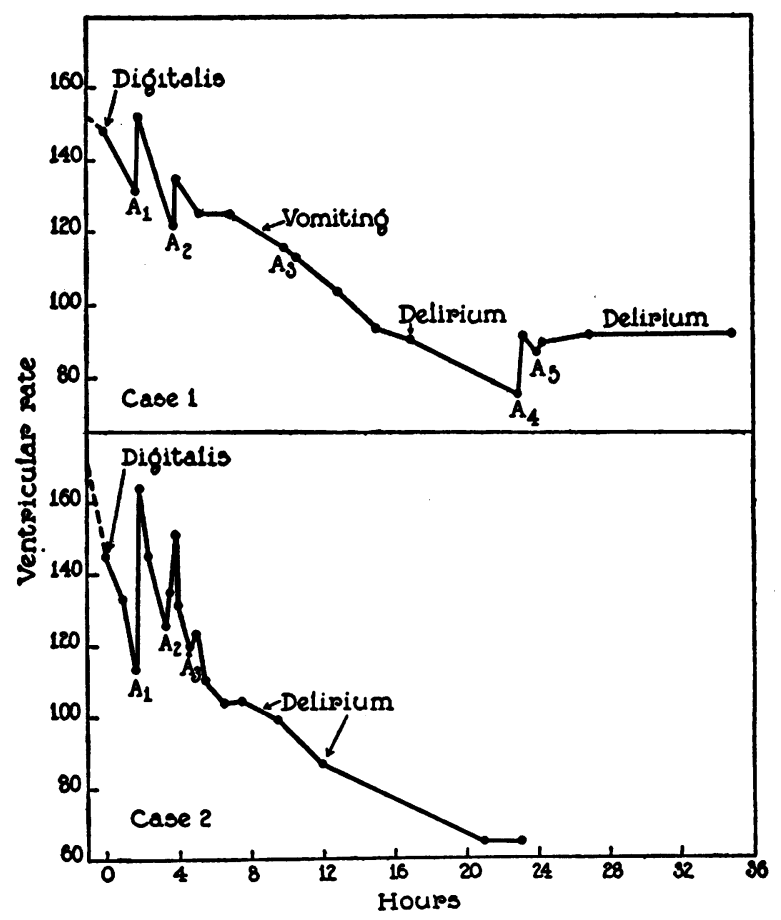

Fig. 2. Atropine Cannot Prevent Slowing by Digrtalis

Case 1. Dose of digitalis, 54 grains. A1, A2, A3, A4, A5 (atropine sulfate, $1 / 25$ grain each).

Case 2. Dose of digitalis, 42 grains. A1, A2 (atropine sulfate, 1/30 grain each). A3 (atropine sulfate, $1 / 60$ grain). the vagi are blocked by atropine, marked ventricular slowing is induced by sufficiently large doses of digitalis. This conclusion was subsequently confirmed by the results obtained in the remaining cases, as may be seen in Table II.

Vagal and extravagal mechanisms shown by the atropine test. At the extremes two types of effect may be seen after large doses of digitalis. These are illustrated in Figure 3. These patients both had advanced congestive heart failure with a rapid ventricular rate (148 and 128 a minute). Each received a large dose of digitalis ( 0.2 and 0.15 cat unit per pound of body weight), and in each, nearly 24 hours later, the ventricular rate had declined to low levels (75 and 61 a minute). Despite these essentially similar conditions, the blocking of the vagus by atropine had little effect in one and a very marked effect in the other. Of these, in one, only 23 per cent of the digitalis slowing was removed, while in the other 100 per cent of the digitalis slowing was abolished, the ventricular rate rising higher than the control rate before the digitalis. In Case 3, therefore, the action of the digitalis was predominantly vagal, and in Case 1, predominantly extravagal (direct action on conduction ${ }^{2}$ ).

2 Luten (7) refers the extravagal factor, in part at least, to reduced excitability of the ventricle. 


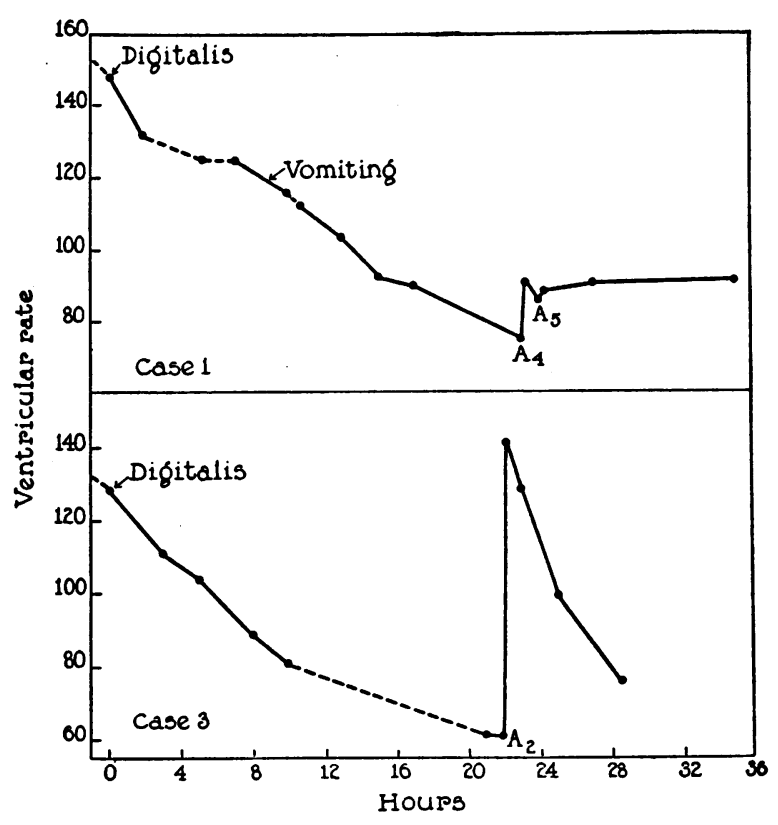

Fig. 3. Vagal and Extravagal Mechanism of Slowing

Case 1. Dose of digitalis, 54 grains. A4, A5 (atropine sulfate, $1 / 25$ grain each). In broken lines changes in rate due to previous doses of atropine are omitted.

Case 3. Dose of digitalis, 24 grains. A2 (atropine sulfate, $1 / 30$ grain). Broken line of same significance as in Case 1.

Factors which determine the mechanism. The next question was: What factors determine whether one or the other mechanism would control the ventricular rate after digitalis-individual peculiarity, the degree of heart failure or of functional improvement, or the dosage of the drug?

Figure 4 shows that it is not a matter of individual peculiarity, for in the same individual the slow heart rate during digitalis action may be at one time under vagal control and at another time under extravagal control. For example, in Case 2 , the control is extravagal 10 hours after 42 grains of digitalis; it is the vagal type (100 per cent release) after 4 days, but it again returns to the extravagal control (only 16 per cent release) on the fourteenth day. Similarly, in Case 3 , the heart rate is slow by a vagal mechanism on the first and second day after the digitalis, but by a predominantly extravagal mechanism on the tenth and eleventh day. In Table II are summarized the observations in all the experiments indicating that one and the same individual may show both types of control.
Figure 5 shows that the mechanism which will control the slow heart rate after digitalis is not directly related to the degree of heart failure. In Case 5, the same mechanism, the extravagal one, which controlled the ventricular rate during the period in which the symptoms of failure had almost completely subsided (loss of 12 pounds of edema fluid) on the eighth day after beginning digitalis, was already in control 8 hours after the first massive dose of $\mathbf{3 5}$ grains, when relatively little clinical improvement was in evidence. In Case 2, the extravagal mechanism predominated in the slowing about 8 hours after 42 grains of digitalis, as shown by the fact that even though the vagi were blocked by atropine the rate did not exceed 104 (reduced from 145). During this period very little clinical improvement was in evidence. By the fourth day marked clinical improvement had taken place, the patient having lost 10 pounds of edema fluid. At this time the control had shifted to the vagal mechanism (rate after atropine release, 161).

Figure 6 shows that the two mechanisms may be seen at different times in a patient without signs or symptoms of heart failure.

The foregoing results show that the vagal and extravagal types of control of the ventricular rate may alternate in the course of digitalization in a manner that seems in no way related to the state of the myocardial function as revealed by the clinical signs and symptoms.

In Table II, the effect of the size of the dose on the mechanism is shown. The dose of digitalis appears to be the only factor consistently related to the mechanism. It is not safe to compare one case with another with respect to the amounts of drug because of differences in tolerance, but the course of events in individual cases shows that when the dose is increased the atropine test reveals a shift from the vagal to the extravagal control of the ventricular rate, and vice versa, when the dose acting upon the heart is reduced. For example, in Case 1, a predominantly vagal type (Case A1, 100 per cent release) 2 hours after the dose of digitalis, became a predominantly extravagal type (Case B1, 23 per cent release) after more digitalis had been absorbed in 23 hours following its administration. In Case 2 , there is the extravagal type of control 8 hours after the large dose of digitalis (see also Figure 5), the 


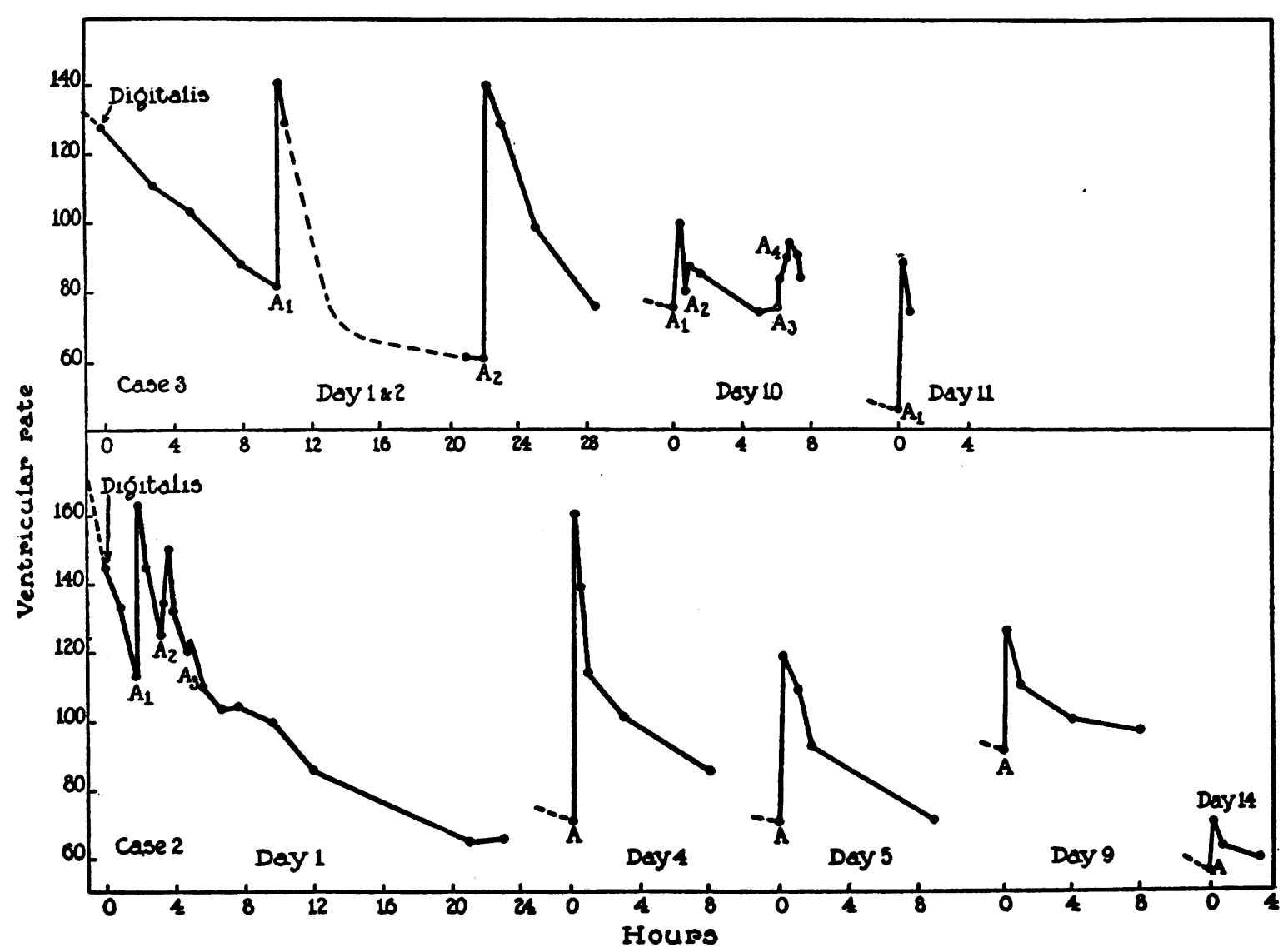

Fig. 4. Either Vagal or Extravagal Control of the Ventricular Rate May Prevail in the Same Individual

Case 3. Dose of digitalis, 24 grains on Day 1; 93 grains more during Days 3 to 9. Each (A) represents $1 / 30$ grain atropine sulfate. Broken line (no observations during the night).

Case 2. Dose of digitalis, 42 grains on Day 1; 36 grains more during Days 6 to 8 . Each (A) represents $1 / 30$ grain atropine sulfate, except $A 3$, and $A$ on Day 5 (1/80 grain each).

vagal type ( 100 per cent release) in 4 days, during which time some of the drug was eliminated, but a return to extravagal control (only 16 per cent release) on the fourteenth day and after more digitalis, a total of 78 grains.

The results in Table II also show that atropine invariably causes some acceleration of the ventricular rate after it has been slowed by digitalis in patients with auricular fibrillation. This applies not only to small doses of digitalis but to maximum doses, those causing nausea and vomiting. The extent to which the most effective dose of atropine will raise the ventricular rate depends upon the degree of the digitalization. After the smaller doses of digitalis the slowing can be entirely abolished by atropine, but after the larger ones the slowing can be only partially abolished by atropine. During the full action of the maximum doses it is not possible to accelerate the ventricular rate appreciably above 100 a minute. In these cases the maximum rate after complete vagal release by atropine is usually considerably below 100 a minute.

\section{COMMENT}

We are now in a better position to comprehend the conflict in the literature regarding the rôle of the vagus in digitalis slowing. In Table III the essentials of three studies have been summarized and compared with the results obtained in our own. An inspection of this table shows that the results in all are qualitatively identical, but quantitatively different and these differences appear clearly to be related to the differences in 


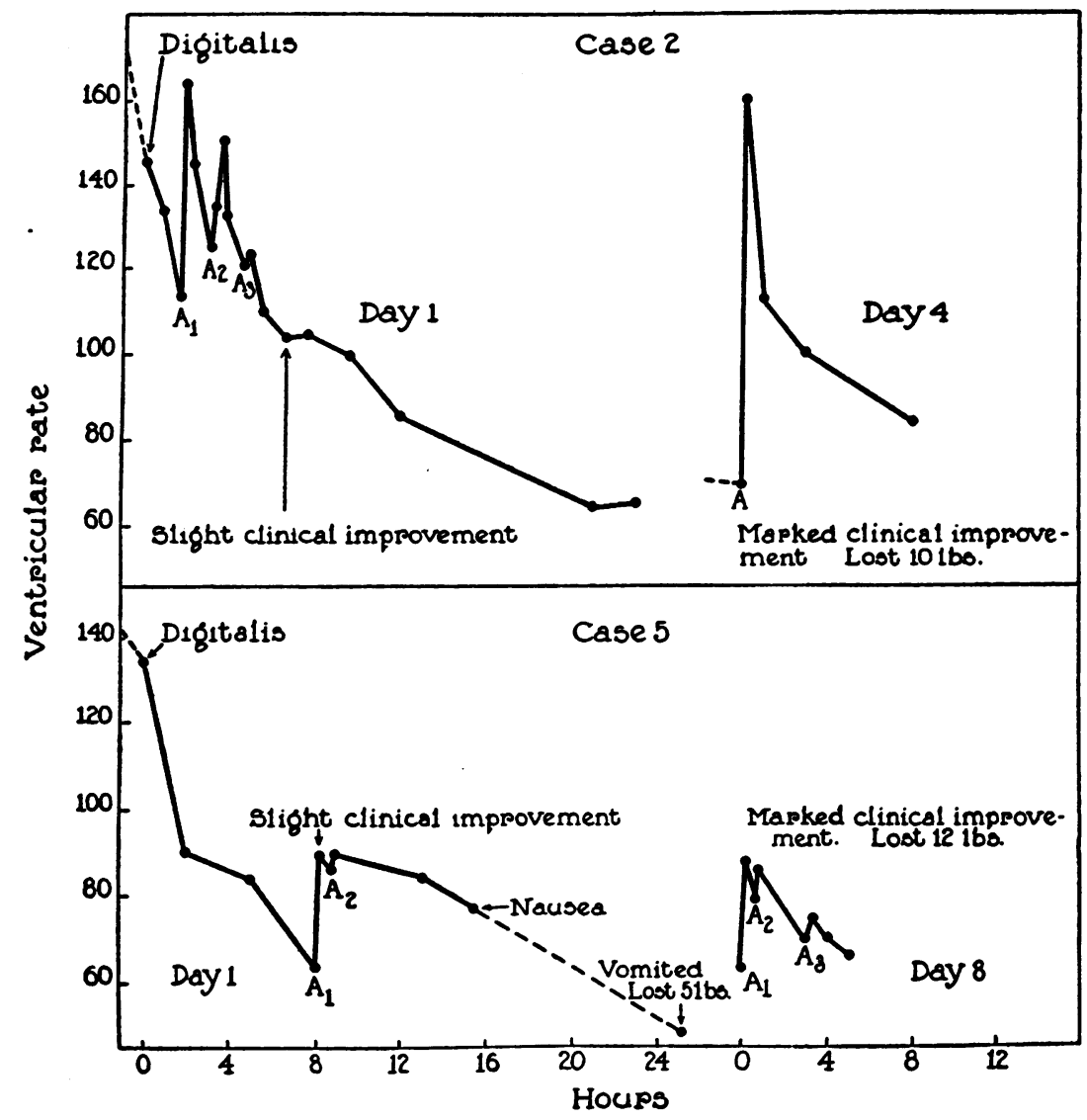

Fig. 5. Improvement of Heart Failure does not Determine the Mechanism OF THE SLOWING

Case 2. See legend of Figure 4.

Case 5. Dose of digitalis, 35 grains on Day 1, and 21 grains more during Days 2 to 8. Each (A) represents $1 / 30$ grain atropine sulfate.

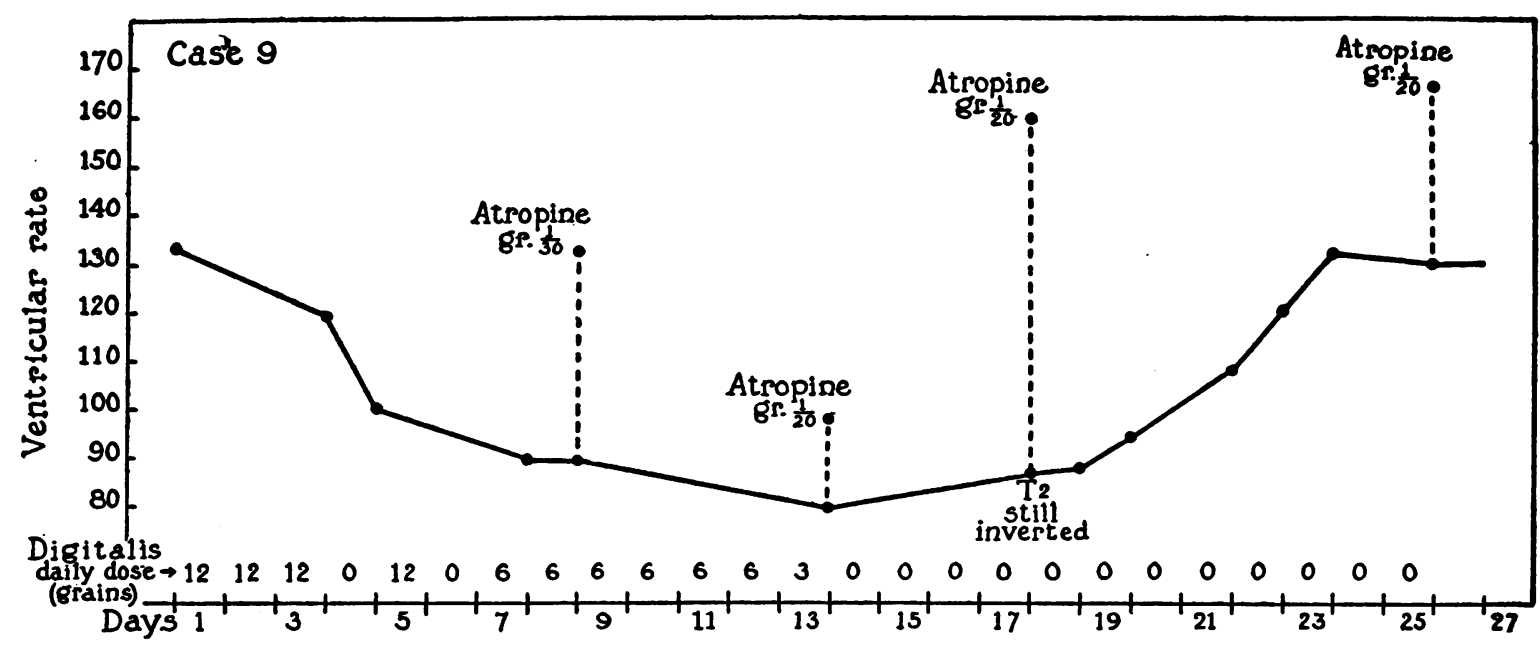

Fig. 6. Vagal and Extravagal Mechanism of Slowing in a Patient without Signs or Symptoms of HeART FaIlure 
TABLE III

Effect of atropine on ventricular rate after digitalis in 4 studies with patients having auricular fibrillation.

\begin{tabular}{|c|c|c|c|c|c|c|c|c|}
\hline Author & $\begin{array}{l}\text { Number } \\
\text { of cases }\end{array}$ & $\begin{array}{c}\text { Average } \\
\text { ventricular } \\
\text { rate } \\
\text { without } \\
\text { digitalis }\end{array}$ & Dose of digitalis & Toxic effects & $\begin{array}{l}\text { Average } \\
\text { ventricular } \\
\text { rate after } \\
\text { digitalis } \\
\text { and before } \\
\text { atropine }\end{array}$ & $\begin{array}{c}\text { Dose of } \\
\text { atropine } \\
\text { sulfate }\end{array}$ & $\begin{array}{l}\text { Average } \\
\text { ventricular } \\
\text { rate after } \\
\text { atropine }\end{array}$ & $\begin{array}{l}\text { Per cent of } \\
\text { digitalis } \\
\text { slowing } \\
\text { abolished } \\
\text { by } \\
\text { atropine }\end{array}$ \\
\hline $\begin{array}{l}\text { Cushny, } \\
\text { Marris, and } \\
\text { Silberberg, } \\
1912 \text { (1) }\end{array}$ & $\begin{array}{l}11 \\
\text { experi- } \\
\text { ments } \\
\text { in } 10 \\
\text { cases }\end{array}$ & $\begin{array}{c}\text { per minute } \\
103 \\
(75-125)\end{array}$ & $\begin{array}{l}0.8 \text { dram of tincture } \\
\text { daily for } 13 \text { days }(0.3 \\
\text { to } 1 \text { dram daily for } \\
\text { from } 5 \text { to } 32 \text { days) }\end{array}$ & $\begin{array}{l}\text { Nausea, } \\
\text { vomiting or } \\
\text { coupling in } \\
9 \text { cases }\end{array}$ & $\begin{array}{c}\text { per minute } \\
65 \\
(52-77)\end{array}$ & $\begin{array}{l}\quad \text { grains } \\
\text { Usually } 1 / 50 \\
\text { subcutane- } \\
\text { ously }\end{array}$ & $\begin{array}{c}\text { per minute } \\
79 \\
(57-93)\end{array}$ & 37 \\
\hline $\begin{array}{l}\text { Lewis, } \\
\text { Drury, } \\
\text { Wedd, and } \\
\text { Iliescu, } \\
1922(2)\end{array}$ & $\begin{array}{l}8 \\
\text { experi- } \\
\text { ments } \\
\text { in } 7 \\
\text { cases }\end{array}$ & $\begin{array}{c}106 \\
(80-130)\end{array}$ & $\begin{array}{l}0.8 \text { dram of tincture } \\
\text { daily for } 10 \text { days ( } 0.7 \\
\text { to } 1.1 \text { dram daily for } \\
\text { from } 7 \text { to } 13 \text { days) }\end{array}$ & Not stated & $\begin{array}{c}65 \\
(52-75)\end{array}$ & $\begin{array}{l}\text { Usually } 1 / 33 \\
\text { to } 1 / 20 \\
\text { intrave- } \\
\text { nously }\end{array}$ & $\begin{array}{c}137 \\
(102-205)\end{array}$ & $100(175)^{*}$ \\
\hline $\begin{array}{l}\text { Porter, } \\
1933 \text { (5) }\end{array}$ & 21 & $\begin{array}{c}128 \\
(72-180)\end{array}$ & $\begin{array}{l}0.12 \mathrm{cc} \text {. of tincture } \\
\text { per lb. of body weight } \\
(0.1 \mathrm{cc} \text {. to } 0.15 \mathrm{cc} .) \\
\text { administered in } 1 \\
\text { dose } 8 \text { hours before } \\
\text { atropine }\end{array}$ & $\begin{array}{l}\text { Vomiting in } \\
1 \text { case }\end{array}$ & $\begin{array}{c}101 \\
(72-156)\end{array}$ & $\begin{array}{l}1 / 25 \text { intra- } \\
\text { venously }\end{array}$ & $\begin{array}{c}\text { Not } \\
\text { stated }\end{array}$ & $\begin{array}{l}100+\text { in } \\
1 / 3 \text { of the } \\
\text { cases; less } \\
\text { than } 100 \\
\text { in } 2 / 3 \text { of } \\
\text { the cases }\end{array}$ \\
\hline \multirow[t]{2}{*}{$\begin{array}{l}\text { Present } \\
\text { study }\end{array}$} & $\begin{array}{l}9 \\
\text { experi- } \\
\text { ments } \\
\text { in } 6 \\
\text { cases }\end{array}$ & $\begin{array}{c}126 \\
(86-148)\end{array}$ & $\begin{array}{l}\text { About } 0.15 \text { cat unit } \\
\text { per lb. of body weight } \\
\text { (see Table II details) }\end{array}$ & None & $\begin{array}{c}86 \\
(58-133)\end{array}$ & $\begin{array}{l}\text { Usually } 1 / 30 \\
\text { or more } \\
\text { intra- } \\
\text { venously }\end{array}$ & 134 & $100(124)^{*}$ \\
\hline & $\begin{array}{l}12 \\
\text { experi- } \\
\text { ments } \\
\text { in } 8 \\
\text { cases }\end{array}$ & $\begin{array}{c}132 \\
(115-148)\end{array}$ & $\begin{array}{l}0.2 \text { to } 0.5 \text { cat unit } \\
\text { per lb. of body weight } \\
\text { (see Table II details) }\end{array}$ & $\begin{array}{l}\text { Coupling or } \\
\text { vomiting in } \\
4 \text { cases }\end{array}$ & $\begin{array}{c}68 \\
(52-86)\end{array}$ & $\begin{array}{l}\text { Usually } 1 / 30 \\
\text { or more } \\
\text { intra- } \\
\text { venously }\end{array}$ & $\begin{array}{c}89 \\
(68-105)\end{array}$ & 34 \\
\hline
\end{tabular}

* These figures above 100 indicate not only the release of digitalis slowing but the extent of the acceleration above the pre-digitalis rate.

the amount of digitalis given. In one and the same patient we obtained the results of Cushny et al. (1) when the doses were large, and the results of Lewis et al. (2) and of Porter (5) when the doses were smaller. It is not possible to compare the doses of digitalis accurately because we have no data concerning their relative potencies, but the effects indicate that the intensity of digitalization was not the same in the three studies. Cushny et al. drew their conclusions from cases of advanced digitalization as seen from the high incidence of toxic effects. ${ }^{3}$ The cases of Lewis et al. were evidently less intensively digitalized, although no statement is made regarding toxic

3 Although their inferences are also invalid on the grounds of inadequate doses of atropine as we have already mentioned, in the light of our experiments it is improbable that even larger doses of atropine would have yielded materially different results. symptoms. The cases of Elsie Porter were, on the other hand, in the lightest degree of digitalization as indicated chiefly by the relatively high average ventricular rate at the time that the atropine test was made. It may be noted, also, that the ventricular slowing in each of three groups of experiments was almost identical, rate 65 (Cushny), 65 (Lewis), and 68 (present study). Slow rate, therefore, was no indication of the mechanism by which the slowing was caused, for in one group with this slow rate atropine abolished the slowing completely and in the other the effect of atropine was relatively slight. This matter will be considered in another communication.

\section{SUMMARY AND CONCLUSIONS}

1. There is no general agreement regarding the rôle of the vagus in the ventricular slowing by 
digitalis, some maintaining that the drug acts mainly on conduction directly, and others, that its action is mediated chiefly or wholly through the vagus.

2. In the present investigation on patients with auricular fibrillation we found, as others have, that paralytic doses of atropine always cause some acceleration of the ventricle which has been slowed by digitalis, and that this effect varies from slight acceleration to complete abolition of the slowing.

3. We have observed, however, that if the doses of digitalis are large enough, atropine cannot prevent digitalis from producing marked slowing of a rapid ventricle (to 100 a minute or slower).

4. In digitalized patients with auricular fibrillation, the ventricle is maintained at a slow rate usually by the summation of two factors: one, a vagal factor (abolished by atropine) and two, an extravagal factor (not abolished by atropine).

5 . In the average case, the vagal factor predominates in the slowing of the ventricle after moderate doses of digitalis, while the extravagal factor predominates after large doses.

6. Which of the two factors (vagal or extravagal) will dominate in the control of the slowed heart rate depends, therefore, upon the degree of digitalization. Contrary to statements found in the literature, our results show that it is not a matter of individual peculiarity, the degree of heart failure, or the length of time the heart has been under the influence of digitalis.

7. The discordant views in the literature regarding the rôle of the vagus, and the factors which alter its rôle, in slowing of the ventricle in auricular fibrillation arise from the failure to make adequate observations on the effect of maximum doses of atropine after different doses of digitalis in one and the same subject.

\section{BIBLIOGRAPHY}

1. Cushny, A. R., Marris, H. F., and Silberberg, M. D., The action of digitalis in therapeutics. Heart, 1912, 4, 33.

2. Lewis, T., Drury, A. N., Wedd, A. M., and Iliescu, C. C., Observations upon the action of certain drugs upon fibrillation of the auricles. Heart, 1922, 9, 207.

3. Cushny, A. R., The Action and Uses in Medicine of Digitalis and its Allies. Longmans, Green and Co., London, 1925.

4. Robinson, G. C., The Therapeutic Use of Digitalis. Williams and Wilkins Co., Baltimore, 1923.

5. Porter, E., The therapeutic use of drugs of the digitalis group. Quart. J. Med., n. s., 1933, 2, 33.

6. Gold, H., Lieberson, A., and Gelfand, B., Mechanism of production of subauricular beats by digitalis bodies. Arch. Int. Med., 1931, 48, 262.

7. Luten, D., The Clinical Use of Digitalis. Charles C. Thomas, Baltimore, 1936. 